\title{
Potential Induced Degradation of CIGS PV Systems: A Literature Review
}

\author{
Pelin Yilmaz, ${ }^{1,2^{*}}$ Jurriaan Schmitz, ${ }^{1}$ Mirjam Theelen ${ }^{2}$
}

\begin{abstract}
This review paper presents an overview of studies of Potential Induced Degradation (PID) in copper indium gallium diselenide (CIGS) photovoltaics. It reviews the observations reported in literature, the proposed origins of this high voltage-difference-driven degradation effect and the applied testing methods. Studies on cell, mini-module and module level are presented and compared. Possible preventive measures against potential induced degradation in CIGS solar devices are also discussed.

*Corresponding author; email: p.yilmaz@utwente.nl

${ }^{1}$ MESA+ Institute for Nanotechnology University of Twente, ${ }^{2}$ TNO partner in Solliance
\end{abstract}

Keywords: $\mathrm{Cu}(\mathrm{In}, \mathrm{Ga}) \mathrm{Se}_{2}$, reliability, potential-induced degradation

Word count: 6432

Abbreviations:

$\begin{array}{ll}\text { PV } & \text { Photovoltaic } \\ \text { CIGS } & \text { Cu(In,Ga)(Se,S) } 2 \\ \text { BIPV } & \text { Building Integrated Photovoltaic } \\ \text { LCOE } & \text { Levelised Cost of Electricity } \\ \text { PID } & \text { Potential Induced Degradation } \\ \text { EL } & \text { Electroluminescence } \\ \text { C-Si } & \text { Crystalline-silicon } \\ \text { IEC } & \text { International Electrotechnical Commission } \\ \text { RH } & \text { Relative Humidity } \\ \text { SIMS } & \text { Secondary lon Mass Spectroscopy } \\ \text { GD-OES } & \text { Glow Discharge Optical Emission Spectrometry } \\ \text { EBIC } & \text { Electron-Beam-Induced Current } \\ \text { TOF-SIMS } & \text { Time-of-Flight Secondary lon Mass Spectroscopy } \\ \text { KPFM } & \text { Kelvin Probe Force Microscopy } \\ \text { CL } & \text { Cathodoluminescence } \\ \text { NREL } & \text { National Renewable Energy Laboratory } \\ \text { SLG } & \text { Soda-lime glass } \\ \text { BSG } & \text { Borosilicate glass } \\ \text { TCO } & \text { Transparent conductive oxide } \\ \text { TPO } & \text { Thermoplastic polyolefin } \\ \text { EVA } & \text { Ethylene vinyl acetate } \\ \text { PVB } & \text { Polyvinyl butyral }\end{array}$




\section{Author Affiliations:}

Yilmaz, Pelin ${ }^{1,2}{ }^{*}$

Schmitz, Jurriaan ${ }^{1}$

Theelen, Mirjam²

$1=$ MESA + Institute for Nanotechnology, University of Twente, Enschede, the Netherlands

$2=$ TNO partner in Solliance, High Tech Campus, Eindhoven, the Netherlands

*= corresponding author details, p.yilmaz@utwente.nl

\section{Introduction}

Photovoltaic (PV) systems are presently one of the frontrunner technologies for 'green' electricity production, with a total installed solar power capacity exceeding $584 \mathrm{GWp}$ by $2019 .^{1}$ One of the PV technologies displaying rapid growth are devices based on thin-film $\mathrm{Cu}(\mathrm{In}, \mathrm{Ga})(\mathrm{Se}, \mathrm{S})_{2}$ (CIGS) absorbers, which have displayed record efficiencies up to $23.35 \%^{2}{ }^{2,3}$ The whole solar stack has a thickness of only a few micrometres by virtue of the direct bandgap. The key benefits of CIGS PV include its attractive temperature dependency, as well as a short energy payback time and advantageous cost projections: thanks to the reduced amount of required material for thin-film solar cells and the possibility to use low-cost manufacturing techniques. ${ }^{4}$ Moreover, the feasibility to deposit flexible PV devices with an aesthetically pleasing colour on a large range of substrates, including glass, plastics, and metal foils, allows the usage of the CIGS technology in many new applications: these include integration into vehicles, astronautics, and portable devices, as well as building integrated PV (BIPV). ${ }^{4}$

An additional consideration for the deployment of a photovoltaic technology, perhaps the most important one, is its levelised cost of electricity (LCOE). ${ }^{5}$ Besides production cost and module efficiency, the LCOE strongly depends on the efficiency degradation over time and the probability of failures. One important module degradation mechanism, that is common to all PV technologies including the CIGS PV systems, is through Potential Induced Degradation (PID), which was firstly coined by Pingel et al. ${ }^{6,7}$ It occurs when a high potential difference forms between the solar cells in the module and the module frame. This is notably observed in PV systems in the field when numerous PV modules are connected in series (strings) in order to build up a high voltage output with minimum resistance losses. At the same time, the module frames on the other hand are grounded for safety purposes. ${ }^{6}$ With maximum system voltages reaching 1000-1500 V in the field, the resulting extremely high potential difference between the cells and the frame can lead to severe degradation of the module leading to power production 
losses. PID has a severe impact on power and lifetime, and is becoming more prominent over time. ${ }^{8}$

This significant reliability problem has been widely studied in recent years. CIGS PV systems have been shown to have higher resistance to PID as to multi-crystalline $\mathrm{Si}$ and a-Si, when compared under the same testing conditions. ${ }^{9}$ Additionally, to our best knowledge, severe PID failures in CIGS PV systems within the field have only been observed at PV modules from a specific batch of one CIGS manufacturer. Still, PID will occur if only the potential differences are large enough, which is likely considering the intention towards increasing the maximum system voltages, to $1500 \mathrm{~V}$ and perhaps even higher, in PV power plants. To contain this reliability risk, it is therefore important to understand the degradation mechanisms and quantify and predict their effect.

Researchers have pointed at leakage currents and sodium migration within the solar stack to be root causes of failure due to PID. However, a complete understanding of this degradation type is still lacking. This paper focuses on CIGS PV systems and reviews the published work in this area. Testing methods are outlined for both modules and cells. The PID phenomenon is then discussed in detail through an overview of studies about the impact on the electrical properties, the migration behaviour of sodium and proposed degradation mechanisms behind this failure. The paper lastly describes possible PID mitigation strategies and damage recovery in CIGS modules.

\section{Field Observations and Testing Methods}

PV experts monitoring grid-connected CIGS PV systems in the field have stated that PID principally depends on the configuration of the grounding and the position of the module within the string, as also observed for other PV technologies. ${ }^{6,10}$ It was reported that the CIGS PV modules only at the negative pole of the string suffer power losses due to PID, with the amount of power loss increasing towards the end of the string. The modules at the further end of the negative string are the most affected as the built-up potential difference between the solar cells and the module frame is the highest at that position. This trend was evidently displayed by camera based electroluminescence (EL) imaging measurements done in the field by PI Berlin (Fig. 1). ${ }^{11}$ In addition to the magnitude of built-up potential difference between the module's active circuit and ground, other factors that influence the PID occurrence include temperature and humidity. For comparison, crystalline-silicon (c-Si) based PV modules were found to be more prone to PID when located in coastal areas with moderately warm climates. ${ }^{10}$ 


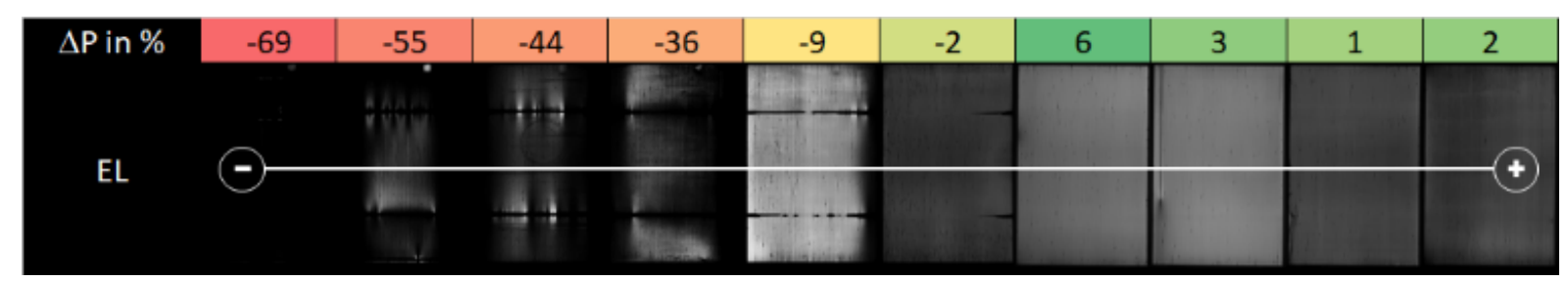

Fig 1. Field observations by PI Berlin over power drop percentages and EL images of the CIGS commercial modules along a string. Modules at the negative pole of the string show a drastic power drop upon PID with darkened EL images, whereas modules at the positive pole are performing well. Image shared by the author of ref. 11.

Based on such observations from the field, an International Electrotechnical Commission (IEC) standardised testing procedure was compiled under IEC 62804 to evaluate PID susceptibility. Currently IEC 62804-1 has been published, however this is only for c-Si systems. ${ }^{12}$ For thin-film PVs a draft, IEC 62804-2, has been compiled and is currently submitted with a forecasted publication date of September 2021. The newly published IEC 61215 also includes a PID test.

\subsection{Module level testing}

The IEC 62804-1 PID test procedure prescribes application of a high voltage stress in a climate chamber. The bias is externally applied via a power source between the grounded metal frame and the solar cells via the module's shorted leads (Fig. 2a). The leakage current is measured via a shunt resistor connected to the circuit. The voltage applied is equal to the maximum system voltage in the atmospheric conditions of $60^{\circ} \mathrm{C}$ and $85 \%$ Relative Humidity $(\mathrm{RH})$ for 96 hours. The control over temperature and humidity is crucial, therefore IEC 62804-1 prescribes the stabilisation of these conditions before the application of the bias. Selection of stress parameters can alternate depending on the purpose of the studies. ${ }^{6}$ One common stress combination of PID test is application of $-1000 \mathrm{~V}$ at $85^{\circ} \mathrm{C}$ and $85 \% \mathrm{RH}$. The negative bias is chosen as the PID problem arises only for the modules grounded at the negative end of the PV string.

The potential-induced loss of electroluminescence as seen in Fig. 1 concentrates at the edges, close to the module frame, where the internal electric field is strongest. The stress is highly nonuniform across the module by nature. A more uniform stress can be imposed by extending the grounded terminal across the entire module. In such a test the degradation process is accelerated and may be easier to analyse. Therefore, an alternative setup for PID test described in IEC 62804-1 adds a grounded conductive layer placed on the top or back side of the module. This layer could be a metal plate or metal foil. Such tests were compared to more conventional PID testing by Boulhidja et al. ${ }^{13}$ They have confirmed that the power degradation of PV modules was noticeably higher when the high voltage application was on the aluminium plate placed on the back or front surface, in comparison to application on the frame only. The bias application on the back surface yielding the worst degradation effects. ${ }^{13}$ 


\subsection{Mini-module and cell level testing}

For modules, studies mainly focus on tracking of the electrical properties upon PID stressing such as I-V characteristics and leakage current measurements. ${ }^{13-17}$ Due to the size and the packaging of the field modules, with front and back glass sheets and the encapsulant, it is more difficult to study the nature of the defects and the root-cause of the degradation mechanisms with laboratory based analysis methods. In-depth microanalytic studies for PID have only been reported with laboratory-made CIGS samples, such as mini-modules or cell level samples. The IEC standardised PID test however has to be adapted for such lab scale studies..$^{9,18-22}$

It should be kept in mind that laboratory studies, especially on small samples, do not represent real life operating conditions in the field and samples may not have the exact module layer stack. The impact of the packaging on PID is excluded in cell tests, while for instance the encapsulant or glass sheets with high electrical resistivity are known to suppress such degradation..$^{9,17}$ This creates a gap between the field and laboratory studies, complicating their comparison towards a full understanding of CIGS PID.

For mini-modules (referred to as coupons in some studies), the bias is applied between a grounded aluminium plate placed on mini-modules and the external contacts that were short circuited and strung in parallel, similar to module leads (Fig. 2b). As in the case of module level testing, it is also relevant here whether the aluminium plate is placed on the front or back surface of the mini-module. Alonso-Garcia et al. have reported that applying high voltage from the back side of the mini-modules had more severe PID effects under same conditions in comparison to application from the front side. ${ }^{18}$ Fjällstrom et al. have developed a PID setup for cell testing, where an external bias of $50 \mathrm{~V}$ is applied between the substrate and the substrate/Mo interface (Fig. 2c). ${ }^{23}$

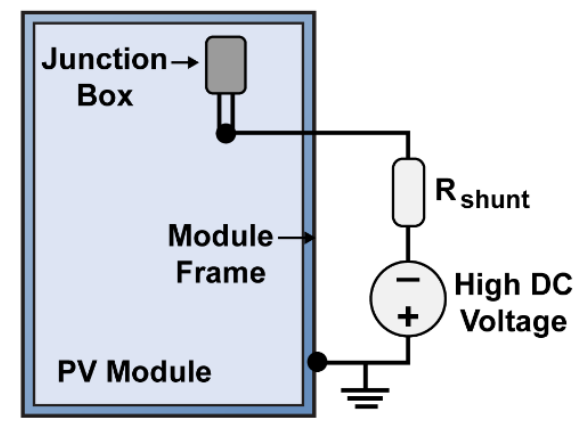

Figure 2a. Field module testing 


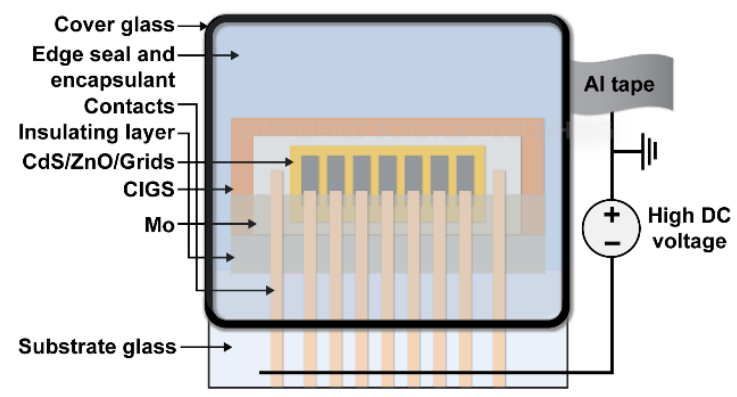

Figure 2b. Mini-module testing

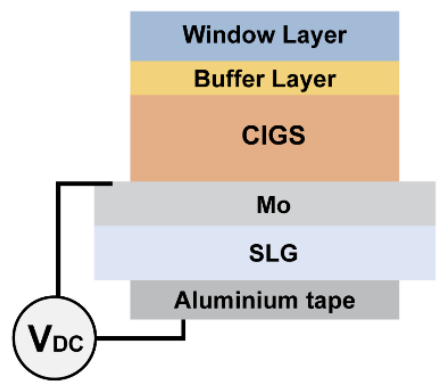

Figure 2c. Cell testing

Figure 2 PID test setups for (a) field modules, (b) mini-modules with aluminium plate placed at the back, (c) cell level samples. Schematics drawn after refs. 17, 18, and 23.

\subsection{Acceptance of IEC standards.}

Additionally, there is concern in the PV community that the tests following an IEC standardised PID test procedure may be inadequate to ensure long-term stability and performance. ${ }^{24}$ In an online survey during a Conexio Webinar in May 2020, 50 PV experts were asked whether they think the IEC standardised test is sufficient to expect their PV system to be PID-free for the full service life. $67 \%$ of the participants said they do not expect it to be sufficient; all others replied they do not know. ${ }^{25}$ This concern rises from mixed results and poor correlations between outdoor and indoor tests. The lack of a settled procedure for all and each of PV technologies creates additional uncertainties in comparing and understanding PID phenomena.

\section{Phenomenology of PID}

A first step towards the understanding of PID is to analyse the physical and electrical evolution of CIGS devices over time under PID stress conditions.

\subsection{Leakage current formation}

The leakage current that flows between the cells and the grounded frame might be indicative of PID. ${ }^{17}$ Voswinckel et al. described four main pathways from frame to the solar cells that leakage 
currents can take in CIGS solar modules, as indicated by red arrows in Fig. 3. They can flow through:

(1) the cover glass and encapsulant,

(2) the edge sealing and the encapsulant,

(3) the edge sealing and the interface of encapsulant and substrate glass, and

(4) the substrate glass.

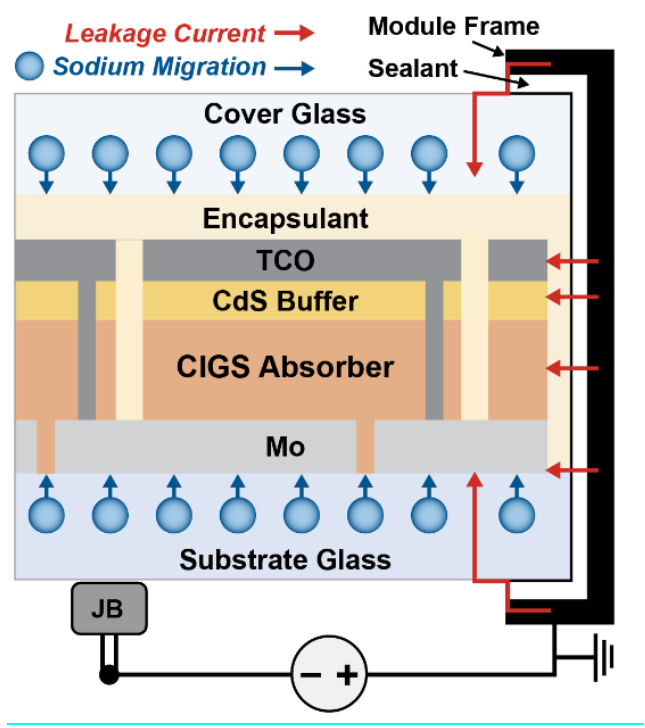

Figure 3. Main leakage current paths and the direction of Na migration in CIGS thin film PV modules. Schematic reillustrated from ref. 17. Copyright Elsevier.

The amount of leakage current along each pathway has been analysed in a series of experiments, where the total leakage current was measured through a shunt resistor. Leakage currents through the cover glass and through the substrate glass are found to be the main contributors to the total leakage current; leakage currents through edge sealings are minor and can be neglected. ${ }^{17}$ The magnitude and the direction of the leakage currents depend on the amount and polarity of the bias applied, and certainly the electrical resistance of the chosen path. The resistivity of the pathways depends on the conductivity of the materials along the path including glass and the encapsulant and therefore also on the temperature and humidity. It has been reported that leakage current follows an Arrhenius type of dependence on temperature. ${ }^{17}$ On the other hand, high humidity increases the conductivity of the glass surfacewhich will increase the flow of leakage currents. Berghold et al. confirmed these relations with their field monitoring data. According to their measurements, the leakage current peaks in the mornings in presence of a morning dew and then increases again around midday when the temperature peaks. ${ }^{10}$

It has been proposed that PID power degradation can be directly correlated to the total leaked charge, that is, the leakage current integrated over time. ${ }^{14,17,26}$ Voswinckel et al. plotted the normalised module power of the modules over the calculated transferred charge during the PID 
test. ${ }^{17}$ Over time, the power loss through PID accumulates, as does the total leaked charge. Both follow a characteristic S-shaped curve on a linear-log representation (cf. Fig. 4). Interestingly, the curve remains unaffected when the stress voltage is changed; yet, different encapsulant materials or stress arrangements do yield different curves. ${ }^{17}$ The observed voltage independence may allow a straightforward translation of voltage-accelerated laboratory tests to field conditions. Further, once the early part of the curve is known for a specific module, the leakage current flowing in outdoor conditions provides a direct means to predict the PID lifetime for that module in a specific climate. ${ }^{26}$

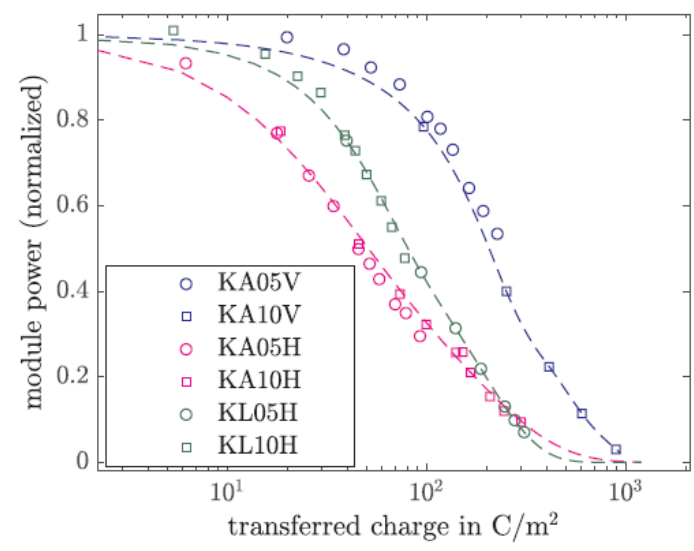

Figure 4. Relative module power versus transferred charge. (Acronyms: $(K)$ is for climate chamber; $(A)$ is for PVB encapsulant; (L) is EVA encapsulant; (10) is equal application of $1000 \mathrm{~V}$ whereas (05) is for $500 \mathrm{~V}$; (V) indicates bias application through the cover glass, $(\mathrm{H})$ indicates bias application through the back glass) Reprint from ref. 17. Copyright Elsevier.

Since atmospheric conditions immensely influence the leakage current behaviour, simulations incorporating annual weather data further improve such predictions. Weber et al. have simulated the module lifetimes of several PV technologies for selected countries. For CIGS systems, the module lifetime was predicted to be as low as 13 years under negative bias for a humid and hot place like Kuala Lumpur. On the other hand, simulations forecasted that PID would be unlikely to occur on dryer or cooler locations like Berlin and Tucson. ${ }^{26}$ It should again be highlighted that such assessments rely on the assumption that power losses due to PID and total leakage charge are directly correlated. This assumption likely loses validity when various degradation phenomena interact. ${ }^{11}$

Power losses due to PID in CIGS systems are driven by drastic drops of open-circuit voltage $\left(V_{o c}\right)$ and fill factor $(F F)$, whereas the short-circuit current density $\left(J_{s c}\right)$ and shunt resistance $\left(R_{s h}\right)$ often remain unaffected. However, there were reported cases where longer stress times resulted in overall poor I-V characteristics. ${ }^{13,16,27,28} \mathbf{F i g . ~} \mathbf{5}$ shows representative J-V curves from a cell based study, where $50 \mathrm{~V}$ of bias was applied at $85^{\circ} \mathrm{C}$ in air. Initially, only $\mathrm{V}_{\text {oc }}$ and FF decrease, followed by a decrease in $J_{s c}$ and $R_{s h}$ at longer stressing times. 


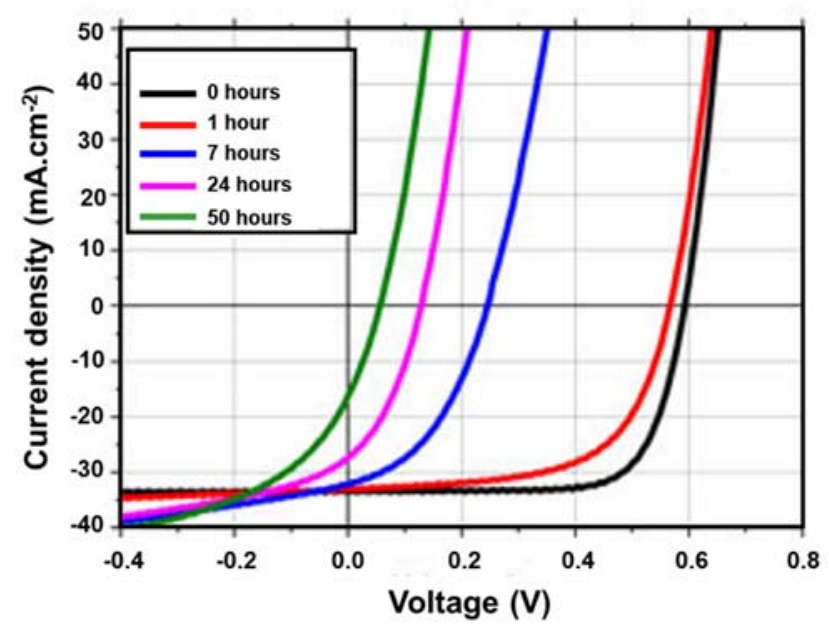

Figure 5. Representative J-V curves of laboratory scale $5 \times 5 \mathrm{~cm}^{2} \mathrm{CIGS}$ sample. PID test conducted at 85 ${ }^{\circ} \mathrm{C}$ in air with a bias application of $50 \mathrm{~V}$ between the molybdenum contact and back-grounded aluminium plate. Reprint from ref. 27. Copyright IEEE.

\subsection{The role of sodium in PID}

$\mathrm{I}-\mathrm{V}$ measurements do not provide a direct explanation of degradation mechanisms. A better insight can be developed with microanalytic studies. Researchers have therefore undertaken investigations at the micrometer scale, particularly concentrating on sodium. Sodium is highly mobile, and highly available in the substrate and the cover glasses of CIGS modules. Typically soda-lime glasses containing more than $15 \% \mathrm{Na}_{2} \mathrm{O}$ are employed. ${ }^{6}$ To study the role of sodium in PID, Fjällstrom et al. compared the PID behaviour of CIGS cells on glass substrates of varying sodium content. Samples with sodium-free substrates as well as with low content sodium substrates survived the test, whereas sodium-rich substrates exhibited significant PID behaviour with severe $\mathrm{V}_{\mathrm{oc}}$ and FF loss. ${ }^{27}$

The result was the same in a study by Yamaguchi et al. They have tested a mini-module with a cover glass without any sodium content. It outperformed the mini-module with conventional tempered cover glass, indicating sodium as the main culprit for this degradation. ${ }^{9}$ On the other hand it is also known that the efficiency of CIGS devices can be improved by sodium doping through defect passivation at grain boundaries. This makes the presence of sodium rather complex in CIGS devices compared to other PV technologies. ${ }^{29}$ The amount and distribution of sodium determines whether it plays a beneficial or detrimental role in the CIGS performance. ${ }^{21}$

Sodium is believed to be driven from the glass substrate or the cover glass to the solar cell layers by a combination of heat and electrical bias. According to Harvey et al., the electrical bias gives an additional driving force for sodium to drift from the glass to the molybdenum layer, while the sodium migration from molybdenum to the adjacent layers of the CIGS solar cell is solely driven by diffusive driving forces following Fick's law. Muzzillo et al. conducted tests on 
encapsulated coupons at $85^{\circ} \mathrm{C}$ and low humidity with and without an electrical bias. A small $\mathrm{V}_{\mathrm{oc}}$ and efficiency drop was observed within 100 hours for the samples under heat and humidity stress without bias, which was attributed to the redistribution of alkali elements through diffusion. On the other hand, the samples that were PID stressed with a bias of $-1000 \mathrm{~V}$ under the same ambient conditions, exhibited catastrophic PID behaviour within only 25 hours. To affirm the impact of heat on the PID, Xiao et al. compared two mini-module samples under the same electrical bias of $-1000 \mathrm{~V}$ but at two different temperatures. The sample stressed at room temperature lasted more than a month, whereas the sample stressed at $85^{\circ} \mathrm{C}$ degraded within 18 hours.

These studies indicate that Potential Induced Degradation is primarily due to the electrical bias that causes a physical drift of sodium to the molybdenum layer, which is followed by its subsequent diffusion into the different layers of the CIGS solar cell stack. ${ }^{21}$ It should be noted that the displacement of sodium will slow down over time. It is abundant in soda lime glass, but the solid solubility of sodium is limited in each layer of the PV stack. Also, if sodium ions accumulate, a charge sheet builds up that creates a repelling electrostatic force against further accumulation. Chemical, photochemical or electrochemical reactions involving sodium may also play a role.

Overall, it is the accumulation and distribution of excess sodium within the CIGS layers that is reported to be the culprit for deterioration of electrical properties leading to performance losses and failure.With these observations, we can now turn to the question which mechanisms degrade CIGS modules during PID stress.

\section{Degradation Mechanisms}

The degradation mechanisms governing PID have been studied, and have been reported to vastly differ between PV technologies. For C-Si PV systems, two main degradation mechanisms have been proposed: PID-shunting formed at stacking faults by accumulated sodium and a surface polarisation effect due to the accumulation of charges at the cell surface leading to high surface recombination. ${ }^{30,31}$ Such mechanisms have not been reported for CIGS PV systems. Investigations of PID in CIGS focus on sodium migration phenomena down to the microscopic level. Characterisation tools such as Secondary lon Mass Spectroscopy (SIMS) and Glow Discharge Optical Emission Spectrometry (GD-OES) have been used to examine the sodium concentration as a function of depth before and after PID stress. This information is complemented with electrical parameters from Current-Voltage (I-V) and Capacitance-Voltage $(\mathrm{C}-\mathrm{V})$ measurements in experimental studies. The proposed degradation mechanisms for PID in CIGS PV devices, following from such measurements, are presented and discussed below (Published studies are listed in Table 1). 
Fjällstrom et al. applied $50 \mathrm{~V}$ to $5 \times 5 \mathrm{~cm}^{2}$ unpackaged cells at $85^{\circ} \mathrm{C}$ in air and monitored $\mathrm{V}_{\mathrm{OC}}$ and FF. After stress, an increased sodium concentration was detected in the CdS layer and in the upper region of the CIGS layer, likely originating from the substrate glass. ${ }^{27}$ From the GDOES data it was not possible to determine whether the sodium had accumulated at the CIGS/CdS interface or only in the CdS layer. The authors speculated that the sodium increase degrades the cell's electrical properties even to a degree that the $p-n$ junction is destroyed. Extra sodium atoms acting as compensation donors are believed to lower the effective doping of the CIGS, which is supported by their observation that the space charge region was larger in the degraded cells. ${ }^{27}$ Salomon et al.'s studies also supported this claim, stating that the root cause of the $V_{o c}$ drop is the lower doping density and lower minority carrier lifetime, where a larger space charge region width was confirmed by CV and Electron-Beam-Induced Current (EBIC) measurements. ${ }^{22}$ In those studies the PID stressing was done on unpackaged minimodules of $10 \times 10 \mathrm{~cm}^{2}$ with an application of $-1000 \mathrm{~V}$ at $70{ }^{\circ} \mathrm{C}$ and $10 \% \mathrm{RH}$. Their GD-OES analysis revealed an increased sodium concentration in the CdS buffer layer and the CIGS absorber layer, but also segregation of sodium on the $\mathrm{ZnO}$ :Al surface was detected after longer testing times.

Muzzillo et al. also observed significant sodium accumulation near the CIGS/CdS p-n junction after PID by SIMS measurements, increasing from 1.2 to $4.2 \times 10^{19} \mathrm{~cm}^{-3}$. They also suggested that PID occurs through a damaged p-n junction. The pile up of sodium at the CIGS/CdS interface could cause interstitial defects within the CdS layer and act as compensating acceptors to reduce the carrier concentration. Excessive sodium can also induce shunting and interfacial recombination. ${ }^{21}$ Xiao et al. detected high sodium concentrations at the TCO and CdS layer, and also at the upper layer of CIGS with TOF-SIMS analysis when they tested mini-modules with a bias of $-1500 \mathrm{~V}$ applied at $85{ }^{\circ} \mathrm{C}$. They reached similar conclusions of sodium accumulation damaging the p-n junction and completely shunting the device, also based on insitu analysis Kelvin Probe Force Microscopy (KPFM) and I-V measurements in the dark (Fig. 6). Sodium is claimed to either act as an impurity or as a cause of defects in the CIGS layer; within the CdS layer it can create deep-level defects when it substitutes at Cd sites. Sodium induced defects can then capture free carriers, leading to a larger depletion width and a leaky junction. ${ }^{32}$ 

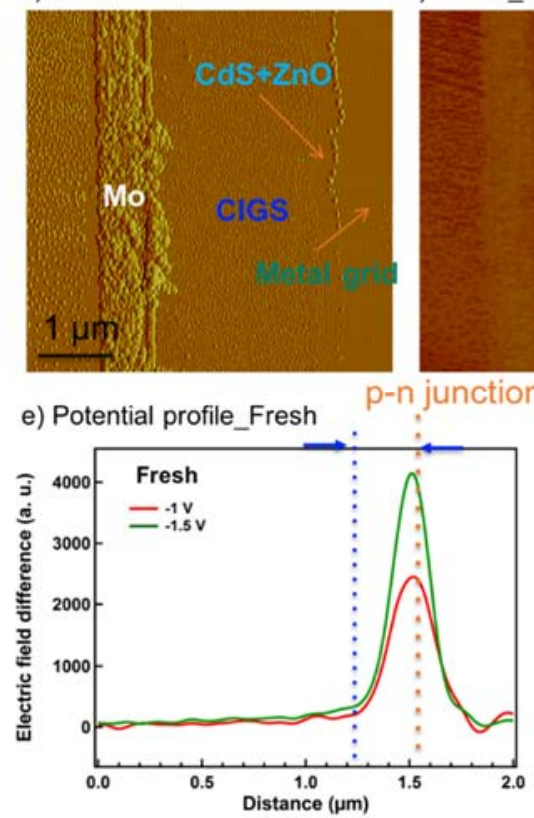

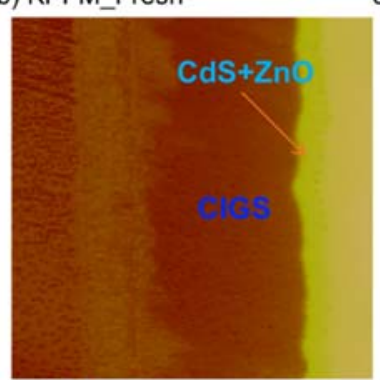

f) Potential profile_10- $\mathrm{p}-\mathrm{n}$ junction

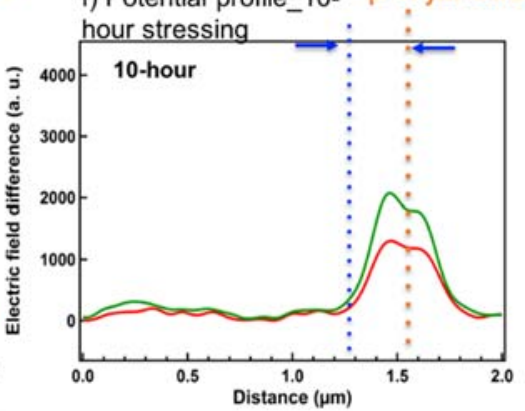

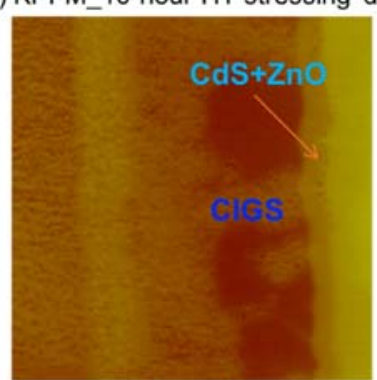

g) Potential profile_18-hour

Figure 6. Kelvin Probe Force Microscopy (KPFM) results for a CIGS cell after PID stressing $\left(-1500 \mathrm{~V}\right.$ at $85^{\circ} \mathrm{C}$ for 18 hours). (a) AFM image and (b) KPFM images taken before the PID stressing. KPFM images taken after (c) 10 hours and (d) 18 hour stressing. (e-g) The potential profiles during PID stressing, where the orange dashed line shows the location of the $p-n$ junction, and the distance between the blue and the orange lines estimates the width of depletion region. (f) Potential profile after 10 hours of stressing with electric field dropped to half compared to (e) initial stage. (g) Potential profile after 18 hours of PID stressing that shows a collapsed p-n junction. Reprint from ref. 32. Copyright IEEE

Alonso-Garcia et al. conducted I-V measurements in the dark upon PID testing samples with an application of $-1000 \mathrm{~V}$ at $85^{\circ} \mathrm{C}$. The PID damage was observed to proceed in two stages. In the first stage, there was an increase of saturation current, which was attributed to sodium migration to the $\mathrm{CdS} / \mathrm{ZnO}$ layer reducing the ionised carrier concentration and built-in potential. This stage was followed by a decrease in shunt resistance $R_{\text {sh. }}{ }^{18}$

Another common observation from the aforementioned studies is that the most catastrophic PID behaviour happens when the polarity of the applied voltage is negative and grounding is done from aluminium placed on the substrate glass. An opposite observation has been reported by Sakurai et al.: a linear power degradation occurred on mini-modules only when the polarity of the bias was positive $(+1000 \mathrm{~V}) .{ }^{33}$ Light soaking led to full recovery of the damage. A reduction of the carrier concentration in the TCO layer was proposed as a possible explanation of the findings, based on I-V and electroluminescence analysis. The authors further argued that a pileup of negatively charged ions in this TCO layer may explain the observations.

Other studies have related the PID in CIGS PV systems to corrosion of the TCO layer. TCO degradation was even visually detected on modules in a few field studies after PID stressing. ${ }^{11,14}$ Yamaguchi et al. conducted a microscopic study to look into TCO corrosion; where a voltage of $-1000 \mathrm{~V}$ was applied between the leads of a mini-module and an aluminium plate placed on the 
cover glass, at $85{ }^{\circ} \mathrm{C}$ and $2 \% \mathrm{RH}$ for 14 days. Their SIMS analysis showed the sodium signal intensity to be higher in the $\mathrm{ZnO}$ layer and the superficial region of the CdS layer. It was stated that sodium accumulated at the $\mathrm{ZnO}$ layer migrated from the cover glass. No notable increase of sodium was observed in the CdS and CIGS layers. The increment of sodium in the $\mathrm{ZnO}$ layer can lead to an increase of series resistance as substitutional sodium can form deep acceptor levels and increase the resistivity of $\mathrm{n}-\mathrm{ZnO}$ by carrier compensation. ${ }^{9}$ Scanning capacitance microscopy shows a decrease in carrier concentration in the TCO layer after PID stressing (Fig. 7). Additionally, Yamaguchi et al. measured significantly raised ideality factors of their degraded samples in forward bias and proposed that the PID is due to an enhanced recombination caused by a high defect density introduced by sodium. ${ }^{9}$

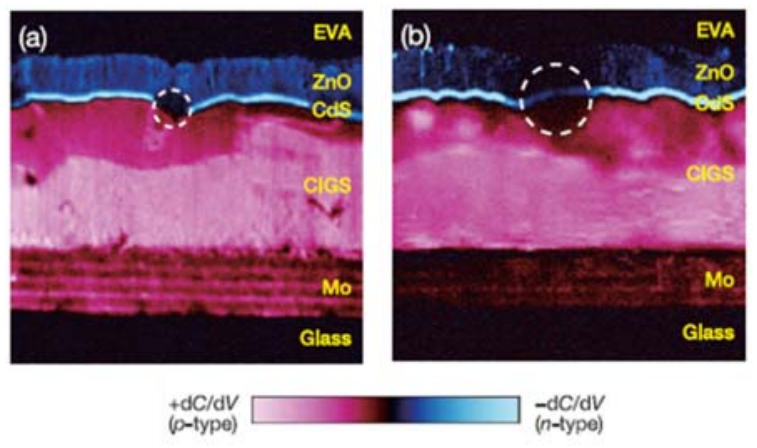

Figure 7. Scanning capacitance microscope images of CIGS mini-modules (a) before and (b) after PID test ($1000 \mathrm{~V}$ at $85^{\circ} \mathrm{C}, 2 \% \mathrm{RH}$ ) for 21 days. Reprint from ref. 9. Copyright IOP Science.

The diffusion of sodium within the layers was claimed to occur mostly via the grain boundaries (as commonly observed in polycrystalline materials). Harvey et al. have performed TOF-SIMS 3-D tomography on various samples to provide 3-D sodium renderings in addition to 1-D depth profiles of sodium, which is what most studies report. In their study, the 1-D depth sodium profile for packaged mini-modules stressed with a bias of $-1000 \mathrm{~V}$ for 25 hours at $85^{\circ} \mathrm{C}$ and $10 \% \mathrm{RH}$ showed a much higher sodium content at the grain boundaries compared to the grain cores. Moreover, the TOF-SIMS 3-D tomography demonstrated that sodium appeared to be uniformly distributed near the back of the absorber layer. It was also observed that sodium notably concentrated at the grain boundaries (Fig. 8). A correlative analysis between cathodoluminescence $(\mathrm{CL})$ and TOF-SIMS further confirmed the high sodium content at the grain boundaries. Upon these observations, it was suggested PID results from sodium migration through the absorber layer via fast grain-boundary diffusion. ${ }^{19}$ 

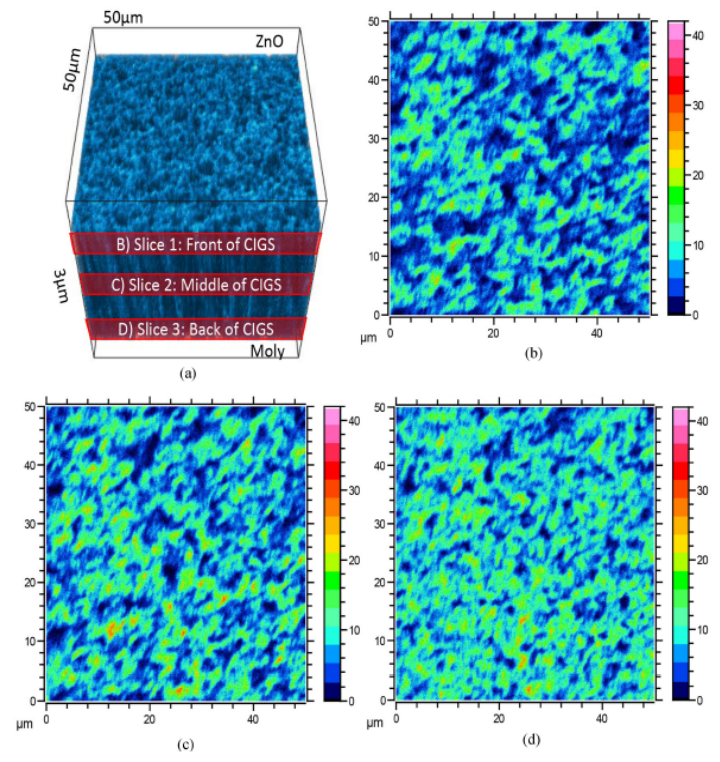

Figure 8. TOF-SIMS 3-D tomography results for a PID-stressed CIGS encapsulated coupon. (PID test: $-1000 \mathrm{~V}$ at $85^{\circ} \mathrm{C}, 10 \% \mathrm{RH}$ ). (a) 3-D reconstruction of $\mathrm{Na}$ in a CIGS device, where the $\mathrm{ZnO}$ and Mo layers are cropped. The colour scale show intensity measured in counts/pixel. (b)-(d) 2-D slices taken from the parts highlighted in red from (a). (b) 2-D image slice from the front of the CIGS absorber layer: $\mathrm{Na}$ is seen in high concentration at the grain boundaries. (c) 2-D image slice from the middle of CIGS absorber layer, where more $\mathrm{Na}$ is detected compared to the front of the CIGS absorber layer. (d) 2-D image slice from the back of the CIGS absorber layer, where high concentration of $\mathrm{Na}$ is seen in the grain cores and at grain boundaries. Reprint from ref. 19. Copyright IEEE.

In addition to studies on sodium, several studies from National Renewable Energy Laboratory (NREL) have also investigated the migration behaviour of other alkali metals, such as potassium, and whether they would have an effect on PID. They have compared the PID behaviour of samples with substrates of soda-lime glass (SLG - Low resistivity and high sodium content) and borosilicate glass (BSG - high resistivity and high potassium content) under same testing conditions. The studies by Alonso-Garcia and Muzzillo et al. showed that BSG samples outperformed the SLG samples with much less PID degradation. ${ }^{18,20,21}$ SIMS analysis by Muzzillo et al. also showed that the potassium concentration also peaks at the CIGS/CdS interface similar to sodium after PID stressing; however, the increase was less pronounced. ${ }^{21} \mathrm{~A}$ similar observation was also reported by Harvey et al. when they compared diffusion behaviour of sodium and potassium migrating from the same SLG substrate. They offered two possible explanations for the little change in overall content of potassium in the absorber layer compared to sodium. One was attributed to the lower concentration of the potassium in the SLG substrate - which is less than $1 \%$ whereas sodium is more than $10 \%$. Another explanation was related to the larger atomic radius of the potassium which will influence its diffusion within the absorber layer. ${ }^{19}$ Overall, these studies once again confirm the major role of sodium in the evolution of PID in CIGS PV systems.

The proposed degradation mechanisms can be summarised in two main scenarios (Schematically illustrated in Fig. 9): PID failure happens either through the p-n junction damage at the CIGS/CdS interface or through the corrosion of the TCO layer. Each scenario depends 
on the migration behaviour of sodium, from where it migrates and at which layer or interface of the CIGS solar stack it accumulates. Varying sodium profiles have been reported with accordingly varying hypotheses for the root-cause of the PID failure. Sodium migrating from the cover glass to the TCO layer increases the series resistance of the layer and results in its corrosion. Contrarily, sodium migration from the substrate glass leads to defective absorber and buffer layers when accumulating at the CIGS/CdS interface, and eventually harms the p-n junction. On the other hand, a direct correlation between leakage current and sodium migration has yet to be confirmed in many studies. We therefore further assume on the basis of the reported findings that leakage current is not a cause of PID but may be an indicator for it. However, we believe that investigation of such a link between two phenomena can be of valuable insight to further understand the root-causes of this degradation type.

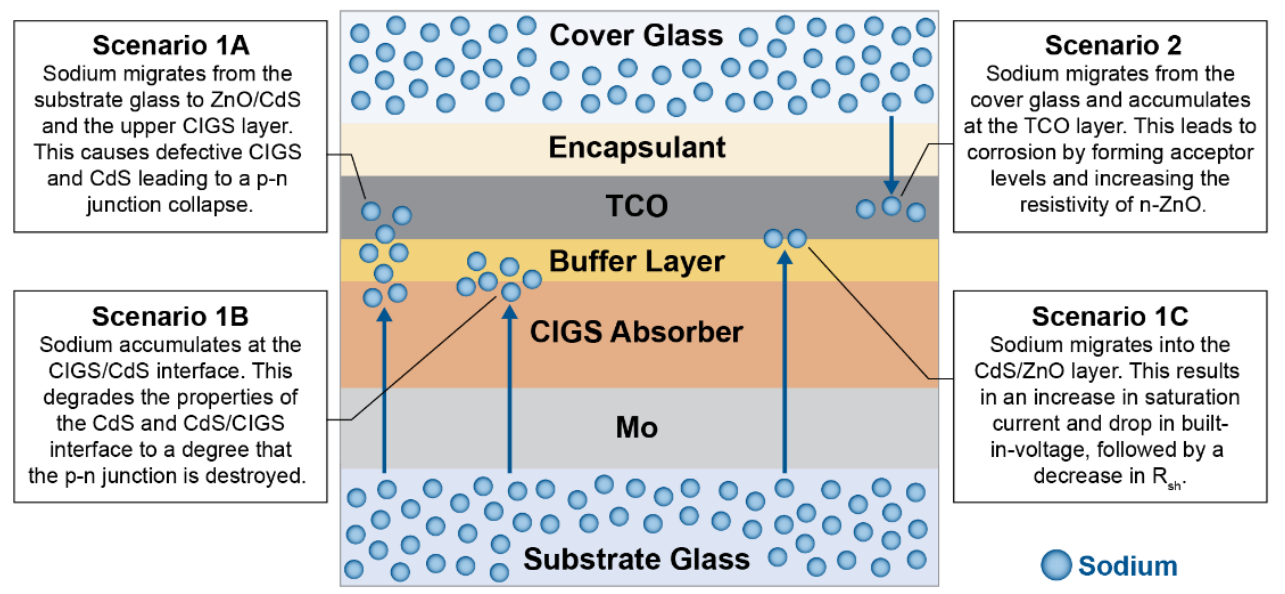

Figure 9. Schematic illustration of proposed degradation mechanisms behind PID failure. Scenario $1 \mathrm{~A}, 1 \mathrm{~B}$, and 1C claims a $p-n$ junction damage caused by sodium migration from the substrate glass. Na profiles reported for each case are different: however, it is commonly proposed that sodium accumulates at the interfaces and cause defective absorber and buffer layers that leads to lower carrier concentration and built-in voltage and eventually leads to a collapsed p-n junction. On the other hand, Scenario 2 proposes a TCO layer corrosion. Na migrates from the cover glass to the TCO layer and increases the resistivity of $\mathrm{Al}: \mathrm{ZnO}$.

The mixed results of PID studies may originate from differences in testing approaches, the choice of materials, and/or the module and solar cell design. A change in test setup such as bias polarity or ambient conditions may lead to contrasting results as a concatenation of effects occurs in the evolution of PID behaviour. Application of bias to an unpackaged sample in dry conditions will for example influence the leakage current flow and the migration of sodium and hence will result in a completely different PID behaviour. It is therefore very important to converge on a standardized testing procedure in order to facilitate easy comparison and combination of findings on different samples in different labs. This will be instrumental for the full understanding of the PID mechanisms.

Table 1. List of published studies that investigated Potential Induced Degradation in CIGS PV systems 


\begin{tabular}{|c|c|c|c|c|c|c|c|}
\hline & $\begin{array}{l}\text { Sample } \\
\text { (Field or Lab } \\
\text { scale) }\end{array}$ & $\begin{array}{l}\text { Test } \\
\text { Parametres }\end{array}$ & $\begin{array}{l}\text { Impact Reported } \\
\text { on Electrical } \\
\text { Properties }\end{array}$ & $\begin{array}{l}\text { Sodium profile, } \\
\text { Sodium } \\
\text { accummulation at: }\end{array}$ & Recovery & $\begin{array}{l}\text { Degradation } \\
\text { Mechanism }\end{array}$ & $\begin{array}{l}\text { Additional } \\
\text { comments }\end{array}$ \\
\hline $\begin{array}{l}27 \\
\text { Fjällstrom et al., } \\
2013 .^{27}\end{array}$ & $\begin{array}{l}\text { Lab, } 5 \times 5 \mathrm{~cm}^{2} \\
\text { (no packaging) }\end{array}$ & $\begin{array}{l}50 \mathrm{~V} \text {, at } 85^{\circ} \mathrm{C} \\
\text { in air }\end{array}$ & $\begin{array}{l}\text { Voc and FF drop, } \\
\text { eventually all } \\
\text { decrease }\end{array}$ & $\begin{array}{l}\text { CIGS/CdS } \\
\text { shown by GD-OES }\end{array}$ & $\begin{array}{l}\text { RT } \\
\text { storage, } 6 \\
\text { months, } \\
\text { recovery } \\
\text { up to an } \\
\text { extent }\end{array}$ & $\begin{array}{l}\text { Voltage dependent } \\
\text { current collection, some } \\
\text { degree of shunting, } \\
\text { overall poor J-V } \\
\text { characteristics. }\end{array}$ & $\begin{array}{l}\text { Investigation of } \\
\text { substrates with } \\
\text { varying sodium } \\
\text { content }\end{array}$ \\
\hline $\begin{array}{l}\text { Fjällstrom et al., } \\
2015 .{ }^{23}\end{array}$ & $\begin{array}{l}\text { Lab, } 5 \text { x } 2.5 \mathrm{~cm}^{2} \\
\text { (no packaging) }\end{array}$ & $\begin{array}{l}50 \mathrm{~V} \text {, at } 85^{\circ} \mathrm{C} \\
\text { in air }\end{array}$ & $\begin{array}{l}V_{\text {oc }} \text { drop, } J_{s c} \text { drop } \\
\text { follows }\end{array}$ & $\begin{array}{l}\text { CIGS/CdS } \\
\text { shown by GD-OES }\end{array}$ & $\begin{array}{l}\text { Positive } \\
\text { bias, dark } \\
\text { storage, } \\
\text { etching of } \\
\text { CdS }\end{array}$ & $\begin{array}{l}\text { p-n junction destroyed, } \\
\text { as extra sodium acts as } \\
\text { compensating donors }\end{array}$ & $\begin{array}{l}\text { SCR width, different } \\
\text { buffer layers }\end{array}$ \\
\hline $\begin{array}{l}\text { Yamaguchi et al., } \\
2015 .^{9}\end{array}$ & $\begin{array}{l}\text { Submodules and } \\
\text { modules } 80 \times 80 \\
\text { and } 120 \times 120 \\
\mathrm{~mm}^{2}\end{array}$ & $\begin{array}{l}-1000 \text { V, } 85 \\
{ }^{\circ} \mathrm{C}, 2 \% \mathrm{RH}\end{array}$ & $\begin{array}{l}V_{\text {oc }} \text { drop, ideality } \\
\text { factor increase }\end{array}$ & $\begin{array}{l}\text { TCO } \\
\text { Shown by SIMS }\end{array}$ & $\begin{array}{l}\text { Positive } \\
\text { bias, dark } \\
\text { storage }\end{array}$ & $\begin{array}{l}\text { Sodium migrates and } \\
\text { accumulates from cover } \\
\text { glass to } \mathrm{ZnO} \text { and } \\
\text { increase the electrical } \\
\text { resistivity }\end{array}$ & $\begin{array}{l}\text { Comparisons of } \\
\text { encapsulants, and } \\
\text { other PV systems }\end{array}$ \\
\hline $\begin{array}{l}\text { Hacke et al., } \\
2015 .{ }^{14}\end{array}$ & Field modules & $\begin{array}{l}-/+1000 \mathrm{v} \mathrm{V} \\
\text { at } 85^{\circ} \mathrm{C} \\
85 \% \mathrm{RH}\end{array}$ & $V_{o c}, F F, I_{s c}$ drop & -- & -- & $\begin{array}{l}\text { Charge carrier } \\
\text { concentration or lifetime } \\
\text { reduction, TCO } \\
\text { corrosion }\end{array}$ & $\begin{array}{l}\text { Also includes CdTe } \\
\text { systems }\end{array}$ \\
\hline $\begin{array}{l}\text { Weber et al., } \\
2015 .^{26}\end{array}$ & Field modules & $\begin{array}{l}-/+1000 \mathrm{~V} \text { at } \\
85^{\circ} \mathrm{C}, 85 \% \\
\mathrm{RH}\end{array}$ & & -- & -- & TCO corrosion & $\begin{array}{l}\text { Module lifetime } \\
\text { predictions }\end{array}$ \\
\hline $\begin{array}{l}\text { Bouldhidja et al., } \\
2017 .{ }^{16}\end{array}$ & Field modules & $\begin{array}{l}-/+1000 \vee \text { at } \\
85^{\circ} \mathrm{C}, 85 \% \\
\mathrm{RH}\end{array}$ & $V_{o c}$ and FF drop & -- & $\begin{array}{l}\text { Positive } \\
\text { bias, light } \\
\text { soaking }\end{array}$ & -- & Frame vs foil contact \\
\hline $\begin{array}{l}\text { Muzzillo et al., } \\
2018 .^{21}\end{array}$ & $\begin{array}{l}\text { Coupons. } 7.5 \mathrm{x} \\
7.5 \mathrm{~cm}^{2} \\
\text { encapsulated } \\
\text { - Coring }\end{array}$ & $\begin{array}{l}-1000 \mathrm{~V} \text { at } \\
85^{\circ} \mathrm{C} \\
10 \% \mathrm{RH}\end{array}$ & $\begin{array}{l}V_{o c}, F F \text {, efficiency } \\
\text { drop }\end{array}$ & $\begin{array}{l}\text { Both sodium and } \\
\text { potassium peak at } \\
\text { CIGS/CdS interface } \\
\text { shown by SIMS }\end{array}$ & -- & $\begin{array}{l}\text { p-n junction harmed. } \\
\text { Shunting, interface } \\
\text { recombination at further } \\
\text { levels }\end{array}$ & $\begin{array}{l}\text { Comparison of SLG } \\
\text { and BSG subs. And } \\
\text { PDT }\end{array}$ \\
\hline $\begin{array}{l}\text { Sakurai et al., } \\
2019 .^{33}\end{array}$ & $\begin{array}{l}\text { Mini-modules, } \\
18 \times 18 \mathrm{~cm}^{2}\end{array}$ & $\begin{array}{l}-/+1000 \mathrm{~V} \text { at } \\
85^{\circ} \mathrm{C},<10 \% \\
\mathrm{RH}\end{array}$ & Power drop & -- & $\begin{array}{l}\text { Light } \\
\text { soaking }\end{array}$ & $\begin{array}{l}\text { Reduced } \\
\text { the carrier concentration } \\
\text { creating a depleted } \\
\text { region } \\
\text { in the TCO layer. }\end{array}$ & $\begin{array}{l}\text { Positive bias } \\
\text { promotes PID, in } \\
\text { contrast to other } \\
\text { studies }\end{array}$ \\
\hline $\begin{array}{l}\text { Salomon et al., } \\
2019 .{ }^{22}\end{array}$ & $\begin{array}{l}\text { Mini-modules. } 10 \\
\text { x } 10 \mathrm{~cm}^{2} \\
\text { unpackaged }\end{array}$ & $\begin{array}{l}-/+1000 \mathrm{~V} \text { at } \\
70^{\circ} \mathrm{C}, 10 \% \\
\mathrm{RH}\end{array}$ & $\begin{array}{l}V_{\text {oc }}, F F \text { drop, and } \\
\text { eventually } I_{s c} \\
\text { decreases }\end{array}$ & $\begin{array}{l}\text { Accumulation at CdS } \\
\text { buffer layer, } \\
\text { segregation at TCO } \\
\text { layer at higher } \\
\text { exposure times by } \\
\text { GD-OES }\end{array}$ & -- & $\begin{array}{l}\text { Enlarged space charge } \\
\text { region, lowered doping } \\
\text { density due to sodium } \\
\text { accumulation, shown by } \\
\text { EBIC and CV } \\
\text { measurements }\end{array}$ & $\begin{array}{l}\text { Analysis of the effect } \\
\text { of Mo back contact } \\
\text { with different } \\
\text { deposition processes }\end{array}$ \\
\hline $\begin{array}{l}\text { Harvey et al., } \\
2019 .^{19}\end{array}$ & $\begin{array}{l}\text { Coupons. } 7.5 \mathrm{x} \\
7.5 \mathrm{~cm}^{2} \\
\text { encapsulated }\end{array}$ & $\begin{array}{l}-/+1000 \mathrm{~V} \text { at } \\
85^{\circ} \mathrm{C}, 10 \% \\
\mathrm{RH}\end{array}$ & All drop, shunted & $\begin{array}{l}\text { Both at TCO/CdS } \\
\text { and CIGS/CdS } \\
\text { interface } \\
\text { shown by SIMS }\end{array}$ & -- & $\begin{array}{l}\text { Sodium migration is } \\
\text { through fast-grain } \\
\text { boundary diffusion }\end{array}$ & $\begin{array}{l}\text { Comparisons } \\
\text { between } T+R H \text { vs } \\
T+R H+P I D\end{array}$ \\
\hline $\begin{array}{l}\text { Xiao et al., } 2019 . \\
32\end{array}$ & $\begin{array}{l}\text { Coupons. } 7.5 \mathrm{x} \\
7.5 \mathrm{~cm}^{2} \\
\text { encapsulated }\end{array}$ & $\begin{array}{l}-1500 \mathrm{~V} \text { at } \\
\mathrm{RT} / 85^{\circ} \mathrm{C}\end{array}$ & $\begin{array}{l}\text { Dark I-V } \\
\text { measurements } \\
\text { show an increased } \\
\mathrm{J}_{0}\end{array}$ & $\begin{array}{l}\mathrm{ZnO} \text { and CdS, as } \\
\text { well as upper layer } \\
\text { of CIGS shown by } \\
\text { TOF-SIMS }\end{array}$ & -- & $\begin{array}{l}\text { p-n junction damage } \\
\text { and a complete shunt } \\
\text { formation }\end{array}$ & $\begin{array}{l}\text { Comparisons of } \\
\text { stress at different } \\
\text { temperatures, in-situ } \\
\text { KPFM } \\
\text { characterisation }\end{array}$ \\
\hline
\end{tabular}




\begin{tabular}{|c|c|c|c|c|c|c|c|}
\hline $\begin{array}{l}\text { Alonso-Garcia et } \\
\text { al., 2019. }{ }^{18}\end{array}$ & $\begin{array}{l}\text { Coupons. } 7.5 \mathrm{x} \\
7.5 \mathrm{~cm}^{2} \\
\text { encapsulated }\end{array}$ & $\begin{array}{l}-1000 \mathrm{~V} \text { at } \\
85^{\circ} \mathrm{C}, \\
\mathrm{RH}<10 \%\end{array}$ & $\begin{array}{l}\text { Increase of } \mathrm{J}_{0} \text { and } \\
\text { decrease of } \mathrm{R}_{\mathrm{sh}} \text { at } \\
\text { later stages }\end{array}$ & -- & $\begin{array}{l}\text { Positive } \\
\text { bias }\end{array}$ & -- & $\begin{array}{l}\text { Front vs back } \\
\text { contact grounding }\end{array}$ \\
\hline $\begin{array}{l}\text { Muzzillo et al., } \\
\text { 2019. }{ }^{20}\end{array}$ & $\begin{array}{l}\text { Coupons. } 7.5 \mathrm{x} \\
7.5 \mathrm{~cm}^{2} \\
\text { encapsulated }\end{array}$ & $\begin{array}{l}-1000 \mathrm{~V} \text { at } \\
85^{\circ} \mathrm{C}, 10 \% \\
\mathrm{RH}\end{array}$ & $\eta$ drop & $\begin{array}{l}\text { Sodium } \\
\text { accumulation at the } \\
\text { absorber by SIMS }\end{array}$ & $\begin{array}{l}\text { Positive } \\
\text { bias }\end{array}$ & $\mathrm{p}$-n junction harmed & $\begin{array}{l}\text { Effect of } \mathrm{Al}_{2} \mathrm{O}_{3} \\
\text { barrier layer, multiple } \\
\text { bias configurations }\end{array}$ \\
\hline $\begin{array}{l}\text { Voswinckel et al., } \\
2020 .^{17}\end{array}$ & Field module & $\begin{array}{l}500 \mathrm{~V}, 1000 \\
\mathrm{~V}, 85^{\circ} \mathrm{C} \\
20 \% \mathrm{RH}\end{array}$ & $\begin{array}{l}\text { Power loss, } V_{\text {oc }} \\
\mathrm{I}_{\mathrm{sc}} \text { drop }\end{array}$ & -- & $\begin{array}{l}\text { Positive } \\
\text { bias, Light } \\
\text { soaking }\end{array}$ & $\begin{array}{l}\text { Power loss is correlated } \\
\text { to transferred charge for } \\
\text { which leakage current is } \\
\text { responsible }\end{array}$ & $\begin{array}{l}\text { Leakage current } \\
\text { measurements }\end{array}$ \\
\hline $\begin{array}{l}\text { Bouldhidja et al., } \\
2020 .^{13}\end{array}$ & $\begin{array}{l}\text { Commercial } \\
\text { modules }\end{array}$ & $\begin{array}{l}1000 \mathrm{~V}, 85 \\
{ }^{\circ} \mathrm{C}, 85 \% \mathrm{RH}\end{array}$ & $\begin{array}{l}V_{\mathrm{oc}}, F F, I_{s c}, R_{s h} \\
\text { decrease, } R_{s} \\
\text { increase }\end{array}$ & -- & $\begin{array}{l}\text { Positive } \\
\text { bias, Light } \\
\text { soaking }\end{array}$ & Shunting & $\begin{array}{l}\text { Voltage stress at } \\
\text { different } \\
\text { configurations }\end{array}$ \\
\hline
\end{tabular}

\section{Mitigation Approaches}

Given the fact that PID can occur, several mitigation scenarios can be considered. These scenarios are summarised in Fig. 10.

\subsection{System level}

The electrical layout and mounting design are the main factors that prompt PID evolution for all $\mathrm{PV}$ technologies. The electrical layout, i.e. the polarity, position and grounding of the PV modules within the PV string, plays a major role for the evolution of the PID. An electrical layout with a proper grounding system and a limited number of cells in series, combined with the right type of inverter technology, can eliminate the risks for PID. With transformer-based microinverters, it is possible to ground either the negative or the positive pole of the PV string. ${ }^{6}$ Considering that the modules at the negative pole of the string are suffering from PID, transformer-based microinverters can offer a simple solution by solely grounding the negative pole. ${ }^{6}$

On the other hand, the presence of grounded frames and supporting rails is the root cause of the potential difference formation between the solar cells and ground. Hacke et al. conducted PID tests on commercial modules with different mounting design and compared their degradation behaviour. Two-edge-framed modules showed slower degradation compared to four-edge-framed modules. Modules with rear rails did not show degradation at longer times of exposure to bias. ${ }^{34}$ Weber et al. demonstrated different degrees of TCO degradation for C-Si modules that have different mounting designs. Framed modules showed heavy corrosion compared to clamped modules and modules with backrails. ${ }^{24}$ Although these studies have been conducted with c-Si PV solar systems, similar preventive measures can also be applicable to CIGS PV systems. In fact, Hacke et al. showed that also CIGS-based modules with edge seal 
and clips had less power degradation compared to framed modules under the same testing conditions. ${ }^{14}$

\subsection{Module and Cell Level}

The choice of materials in the solar stack and in packaging has a major impact on PID. Manufacturing a PID-free module relies particularly on the encapsulant and glass sheets used as cover and substrate in CIGS PV modules. Researchers have investigated various materials to find out the most PID-resistant stack and packaging combination.

Concerning substrate materials we have already discussed the large effect of sodium presence and content on PID resistance in CIGS modules. In this regard, studies overall encouraged to use glass materials with no alkali element content or with heavier alkali metals (e.g. potassium, rubidium, cesium) in preference to sodium to mitigate the PID effects. The type of encapsulant material has also been reported to play a major part in prevention of PID for all PV technologies. Different encapsulation materials of different types and manufacturers have been tested for cSi PV systems, investigating the influence of the material properties on PID behaviour. Materials with lower polarity and lower water uptake have been shown to increase PID resistivity, where a ranking of TPO (DOW Enlight) > EVA Sky > EVA (486.10) > PVB Trosifol R40 has been reported in a study for C-Si PV systems. ${ }^{35}$ For CIGS PV systems, it has been also reported that an encapsulant with higher bulk resistivity can limit the leakage current flowing from the cover glass. Voswinckel et al. have demonstrated that leakage currents were effectively restricted by (certain type of) EVA encapsulation foil by about half an order of magnitude compared to a PVB encapsulant. ${ }^{9}$ Yamaguchi et al. compared the PID behaviour of two mini-module samples with different encapsulant materials when tested under the same conditions. Mini-modules with highly resistive thermoplastic encapsulant of IO (lonomer, Tamapoly HM-52) showed a higher PID resistance with little efficiency loss within 14 days when compared to mini-modules with conventional EVA encapsulants that had lost $80 \%$ of the efficiency at the same time. ${ }^{9}$

An alternative method to limit the sodium migration can be applied to the solar stack by depositing a barrier layer to block sodium diffusion into the cell. ${ }^{20}$ Muzzillo et al. have demonstrated that the addition of an $\mathrm{Al}_{2} \mathrm{O}_{3}$ diffusion barrier between SLG substrate and the molybdenum back contact had little effect on the leakage current. The sample with $\mathrm{Al}_{2} \mathrm{O}_{3}$ barrier has $10^{4}$ times less sodium concentration in the CIGS layer, and a lower time-zero efficiency than the sample without $\mathrm{Al}_{2} \mathrm{O}_{3}$. An increase in efficiency was initially noted upon bias application due to sodium migration to sodium deficient areas; however, the degradation has eventually occurred at longer stressing time originating from excessive sodium within the absorber layer. Still under same testing conditions, the addition of an $\mathrm{Al}_{2} \mathrm{O}_{3}$ diffusion barrier managed to increase the time to PID failure by $5 x$ in comparison to the sample without a diffusion barrier. The majority of the CIGS manufacturers are known to deposit a sodium barrier layer in their 
solar modules, which could explain why PID is not observed in most of the commercial CIGS modules $^{22}$

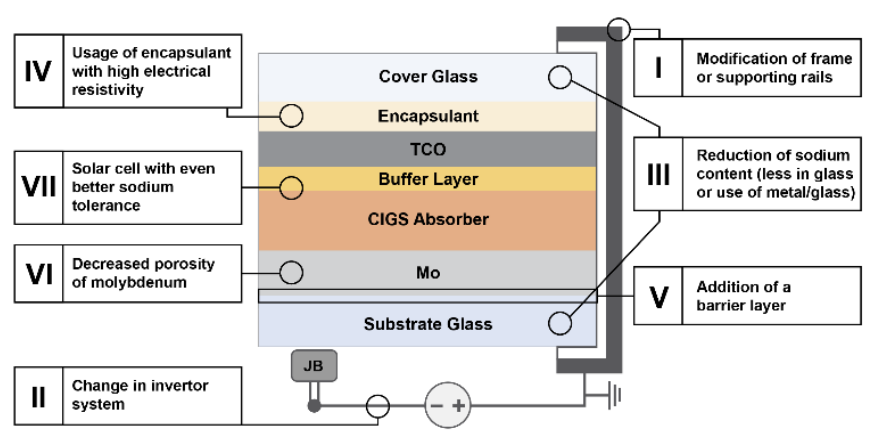

Figure 10. Schematic representation of some of the preventive measures that can be taken to mitigate the effects of PID in CIGS PV systems.

\subsection{Recovery}

Researchers have also investigated whether the Potential Induced Degradation is permanent or (partial) recovery of electrical performance losses is possible. Three main recovery conditions have been analysed:

(1) Dark storage,

(2) Light soaking,

(3) Reversing the polarity of the applied bias.

\subsubsection{Dark storage}

Fjällstrom et al. showed with samples on cell level that dark storage of six months led to an efficiency recovery to $14 \%$ after going down from $15 \%$ to $0 \%$ after PID stressing of 14 days. ${ }^{22}$ With mini-modules that Yamaguchi et al. studied, gradual recovery was observed at room temperature after storing in the dark at room temperature for nine months. ${ }^{9}$ It was suggested that the migration of sodium back to its sources was assisted by the thermal energy at room temperature. Voswinckel et al. however found that at module level for real operating PV power plants, recovery after dark storage was negligible. ${ }^{17}$

\subsubsection{Light soaking}

Voswinckel et al. showed that modules regenerated their power by around 7 relative percent by light soaking after initially losing $17 \% .{ }^{17}$ The improvement of electrical properties was higher for modules that were severely PID damaged. Sakurai et al. also showed a quick and repeatable recovery by light soaking, where the initial power was regenerated within the first few hours. A clear explanation for a recovery mechanism due to light soaking is still lacking. ${ }^{33}$

\subsubsection{Reversing the polarity of applied bias}

Almost all samples at cell and mini-module levels regained their electrical performance close to initial values when the polarity of the initial PID stressing was reversed (i.e. application of 
positive bias). ${ }^{9,18}$ It is believed that both thermal energy and the electric field induced by the applied bias enabled the sodium motion in the opposite direction back to the glass sheets. Yamaguchi et al. demonstrated a recovery of $V_{o c}$, FF and $\eta$ values almost to initial values with a PID recovery test of $+1000 \vee$ for 7 days after the PID test of $-1000 \vee$ for 7 days. The regeneration of electrical performances was attributed to out-diffusion of sodium from the cells. Sodium accumulated within the encapsulant would be drifted back to the cover glass by the applied bias. This would lead to a concentration gradient which would then lead to diffusion of sodium in the cells back to encapsulant. ${ }^{9}$ Alonso-Garcia et al. also attributed the recovery behaviour to the transport of the sodium away from the CIGS/CdS interface, where sodium accumulated after the PID test and damaged the p-n junction. ${ }^{18}$ Fjällstrom et al. showed that the sodium level had decreased at absorber and buffer layers upon application of positive bias, but highlighted that it was still available and higher in concentration compared to the amount before initial PID test with a negative bias application. It should also be pointed out that the recovery was successful in the case of samples with CdS used as buffer layer, whereas no improvements were observed for cells with a buffer layer of $\mathrm{Zn}(O, S)$. This was attributed to different sodium distribution and capacitance responses between the two buffer layers. ${ }^{23} \mathrm{At}$ module level, regeneration of electrical performances up to a certain extent was observed by switching the polarity. ${ }^{13,16,17}$ If such recovery is possible, then a simple solution for PID on system level would be applying a reverse bias to the string at night by the appropriate inverter systems. ${ }^{6}$ Power loss during the day can then be regenerated during the night.

\section{Conclusions}

This review paper aimed to give an overview of research on Potential Induced Degradation in CIGS PV systems, which is a significant reliability problem that results from a high potential difference between the solar cells in the module and the module frame. In comparison to other PV technologies, CIGS PVs have shown a much higher resistivity against PID, with only limited amount of solar modules in the field reported to be affected by this voltage stress. However, taking into account the current targets for building PV power plants with increasing system voltages, the risks of failure due to PID may also emerge for CIGS systems. It is therefore important to study and understand the root-causes of this degradation mode.

IEC standardised testing methods have assisted to investigate the PID phenomenon. The evolution of PID has been associated with leakage current formation and sodium migration from the glass materials to the solar cell stack. In many field studies, power degradation of the PV module was strongly linked to total transferred charge via the leakage current, which gave an opportunity to estimate module lifetimes by simulations modelled on the direct relationship between accelerated laboratory tests and field measurements. On the other hand, laboratory studies in microscale mainly investigated the prominent role of sodium in the evolvement of PID. Different observations have been reported on the migration behaviour of the sodium which have also led to varying opinions on possible degradation mechanisms. One view is that 
accumulation of sodium at the CIGS/CdS interface migrating from the substrate glass damages the $p-n$ junction. On the other hand, corrosion of the TCO layer, caused by sodium migration from the cover glass, has also been reported. These degradation mechanisms reflected in electrical performances with a drop in $\mathrm{V}_{\mathrm{oc}}$ and FF with a stable $\mathrm{I}_{\mathrm{sc}}$, however shunting and overall poor I-V characteristics have also been reported in extreme cases.

Researchers have come up with several PID mitigation approaches. On system level, an electrical layout with well-chosen grounding system and limited peak voltages is a first necessity. On module and cell level, PID resistance can be improved by reducing the leakage current and the sodium migration. Usage of encapsulant and glass materials with high electrical resistivity has been encouraged. It is also recommended to use glass materials with low sodium content for both cover and substrate. At cell level, addition of a sodium diffusion barrier layer was found to be effective. Moreover, it was found that PID in CIGS PV systems can be reversible and modules can regenerate their initial electrical properties through recovering methods of dark storage, light soaking and application of a bias in reversed polarity and light soaking.

Overall, despite the increasing attention on investigation of PID in CIGS PV systems with several published studies and reports, mixed results and poor correlations between results still obscures the understanding of the PID phenomenon. As a crucial step, of a standardized procedure needs to be agreed upon for module, mini-module and cell stressing. We also strongly believe that connecting the expertise of field and laboratory holds the key towards understanding the PID. Performing microanalytic studies by laboratory based techniques on degraded PV modules in field can provide a more detailed insight on the degradation mechanisms behind the real life failures due to PID. Such investigations can offer module- and climate-specific solutions for PID resistivity in PV power plants.

\section{Acknowledgements}

We would like to acknowledge the Early Research Program 'Sustainability \& Reliability for solar and other (opto-)electronic thin-film devices' (STAR) from TNO for funding.

We also would like to thank Thomas Weber, M.Sc., for helpful discussions on PID in thin film technologies.

\section{References}

1. Fraunhofer ISE, Photovoltaics Report, 2020.

2. Green MA, Dunlop ED, Levi DH, Hohl-Ebinger J, Yoshita M, Ho-Baillie AWY. Solar cell efficiency tables (version 54). Progress in Photovoltaics 2019;27:565-575. 
3. Mattos LS, Scully SR, Syfu M, Olson E, Yang L, Ling C, Kayes BM, He G. New module efficiency record: $23.5 \%$ under 1-sun illumination using thin-film single-junction GaAs solar cells. Proc. 38th IEEE Photovoltaic Specialists Conference 2012;003187-003190.

4. Feurer T, Reinhard P, Avancini E, Bissig B, Löckinger J, Fuchs P, Carron R, Weiss TP, Perrenoud J, Stutterheim S, Buecheler S, Tiwari AN. Progress in thin film CIGS photovoltaics - Research and development, manufacturing and applications. Progress in Photovoltaics: Research and Applications 2017;25:645-667.

5. International Renewable Energy Agency (IRENA). Renewable Power Generation Costs 2018.

6. Luo W, Khoo YS, Hacke P, Naumann V, Lausch D, Harvey SP, Singh SP, Chai J, Wang Y, Aberle AG, Ramakrishna S. Potential-induced degradation in photovoltaic modules: a critical review. Energy and Environmental Science 2017;10:43-68.

7. Pingel S, Frank O, Winkler M, Daryan S, Geipel T, Hoehne H, Berghold J. Potential induced degradation of solar cells and panels. Proc. 35th IEEE Photovoltaic Specialists Conference 2010:2817-2822.

8. Jordan DC, Silverman TJ, Wohlgemuth JH, Kurtz SR, VanSant KR. Photovoltaic failure and degradation modes. Progress in Photovoltaics: Research and Applications 2017;25:318-326.

9. Yamaguchi S, Jonai S, Hara K, Komaki H, Shimizu-Kamikawa Y, Shibata H, Niki S, Kawakami $\mathrm{Y}$, Masuda A. Potential-induced degradation of $\mathrm{Cu}(\mathrm{In}, \mathrm{Ga}) \mathrm{Se}_{2}$ photovoltaic modules. Japanese Journal of Applied Physics 2015;54(8):697-708.

10. Berghold J, Koch S, Böttcher A, Ukar A, Leers M, Grunow P. Potential-induced degradation (PID) and its correlation with experience in the field. Photovoltaics International 2013:87-93.

11. Weber T, Hinz C, Leers M, Grunow P, Podlowski L. A Review of Potential Induced Degradation in thin-film plants. Proceedings of 33rd European Photovoltaic Solar Energy Conference and Exhibition 2017:1671-1676.

12. IEC TS 62804-1, Photovoltaic (PV) modules - Test methods for the detection of potential induced degradation - Part 1: Crystalline silicon

13. Boulhidja S, Mellit A, Voswinckel S, Lughi V, Ciocia A, Spertino F, Pavan AM. Experimental evidence of PID effect on CIGS photovoltaic modules. Energies 2020;13:537. 
14. Hacke P, Terwilliger K, Glick SH, Perrin G, Wohlgemuth J, Kurtz S, Showalter K, Sherwin J, Schneller E, Barkaszi S, Smith R. Survey of potential-induced degradation in thin-film modules. Journal of Photonics for Energy 2015;5:053083.

15. Sakurai K, Tomita H, Schmitz D, Tokuda S, Ogawa K, Shibata H, Masuda A. Exploring suitable damp heat and potential induced degradation test procedures for $\mathrm{Cu}(\mathrm{In}, \mathrm{Ga})(\mathrm{S}, \mathrm{Se})$ photovoltaic modules. Japanese Journal of Applied Physics 2018;57:08RG02-1.

16. Boulhidja S, Mellit A, Voswinckel S. Potential-induced degradation test on CIGS photovoltaic modules. Proceedings of 5th International Conference on Electrical Engineering 2017:1-4.

17. Voswinckel S, Mikolajick T, Wesselak V. Influence of the active leakage current pathway on the potential induced degradation of CIGS thin film solar modules. Solar Energy 2020;197:455461.

18. Alonso-Garcia MC, Hacke P, Glynn S, Muzzillo CP, Mansfield LM. Analysis of PotentialInduced Degradation in $\mathrm{Cu}(\mathrm{In}, \mathrm{Ga}) \mathrm{Se}_{2}$ samples. IEEE Journal of Photovoltaics 2019;9:331338.

19. Harvey SP, Guthrey H, Muzzillo CP, Teeter G, Mansfield L, Hacke P, Johnson S, Al-Jassim M. Investigating PID shunting in polycrystalline CIGS devices via multi-scale, multi-technique characterization. IEEE Journal of Photovoltaics 2019;9:559-564.

20. Muzzillo CP, Glynn S, Hacke P, Moutinho HR, Young MR, Repins IL, Mansfield LM. Potentialinduced degradation depends on leakage current and light/electrical bias in $\mathrm{Cu}(\mathrm{In}, \mathrm{Ga}) \mathrm{Se}_{2}$ devices. IEEE Journal of Photovoltaics 2019;9:1852-1856.

21. Muzzillo CP, Glynn S, Hacke P, Moutinho HR, Young MR, Repins IL, Mansfield LM. Potentialinduced degradation of $\mathrm{Cu}(\mathrm{In}, \mathrm{Ga}) \mathrm{Se}_{2}$ solar cells: Alkali Metal Drift and Diffusion Effects. IEEE Journal of Photovoltaics 2018;8:1337-1342.

22. Salomon O, Hempel W, Kiowski O, Lotter E, Witte W, Ferati A, Schneikart A, Kaune G, Schäffler R, Becker M, Schröppel B, Lorbada RV, Mücke D, Walter T. Influence of molybdenum back contact on the PID effect for $\mathrm{Cu}(\mathrm{In}, \mathrm{Ga}) \mathrm{Se}_{2}$ solar cells. Coatings 2019;9:794.

23. Fjällstrom V, Szaniawski P, Vermang B, Salomé PMP, Rostvall F, Zimmermann U, Edoff M. Recovery After Potential-Induced Degradation of Culn ${ }_{(1-x)} \mathrm{Ga}_{x} \mathrm{Se}_{2}$ Solar Cells With CdS and $\mathrm{Zn}(\mathrm{O}, \mathrm{S})$ buffer Llayers. IEEE Journal of Photovoltaics 2015;5:664-669. 
24. Weber T, Berghold J, Heilmann F, Roericht M, Krauter S, Grunow P. Test sequence development for evaluation of potential induced degradation on thin-film modules. Proceedings of 28th European Photovoltaic Solar Energy Conference and Exhibition 2013:3324-3331.

25. Lechner P, Schnepf J, Hummel S, Geyer D, Wittfoth J, Martinez RM, Sanchez-Friera P. Extreme testing of PID resistive c-Si PV modules with $1500 \mathrm{~V}$ system voltage. Proceedings of 37th European Photovoltaic Solar Energy Conference and Exhibition 2020:792-795.

26. Weber T, Berghold J. Potential-induced degradation of thin- film modules: Prediction of outdoor behaviour. Photovoltaics International 2015;27.

27. Fjällstrom V, Salomé PMP, Hultqvist A, Edoff M, Jarmar T, Aitken BG, Zhang K, Fuller K, Williams CK. Potential-Induced Degradation of Culn ${ }_{1-x} G_{a x} S_{2}$. IEEE Journal of Photovoltaics 2013;3:1090-1094.

28. Hacke P, Kempe M, Wohlgemuth J, Li J, Shen YC, Workshop on Crystalline Silicon Solar Cells and Modules: Materials and Processes 2016.

29. Theelen M, Hans V, Barreau N, Steijvers H, Vroon Z, Zeman M. The impact of alkali elements on the degradation of CIGS solar cells. Progress in Photovoltaics: Research and Applications 2015;25:318-326.

30. Swanson R, Cudzinovic M, DeCeuster D, Desai V, Jürgens J, Kaminar N, Mulligan W, Rodrigues-Barbarosa L, Rose D, Smith D, Terao A, Wilson K. the Surface Polarization Effect in High- Efficiency Silicon Solar Cells. Proceedings of 15th International Photovoltaic Solar Energy Conference and Exhibition 2005:410.

31. Naumann V, Lausch D, Hähnel A, Bauer J, Breitenstein O, Graff A, Werner M, Swatek S, Großer S, Bagdahn J, Hagendorf C. Explanation of potential-induced degradation of the shunting type by Na decoration of stacking faults in Si solar cells. Solar Energy Materials \& Solar Cells 2014;120:383-389.

32. Xiao C, Jiang C, Harvey SP, Mansfield L, Muzzillo CP, Sulas D, Liu J, Johnston S, Al-Jassim M. In-situ microscopy characterization of $\mathrm{Cu}(\mathrm{In}, \mathrm{Ga}) \mathrm{Se}_{2}$ potential-induced degradation. Proceedings of 46th IEEE Photovoltaic Specialists Conference 2019:2342-2345.

33. Sakurai K, Tomita H, Tokuda S, Schmitz D, Ogawa K, Shibata H, Masuda A. rapid recovery of CIGS solar cells from PID stress with light soaking. Proceedings of IEEE 46th Photovoltaic Specialists Conference (PVSC) 2019:2000-2002. 
34. Hacke P, Smith R, Terwilliger K, Perrin G, Sekulic B, Kurtz S. Development of an IEC test for crystalline silicon modules to qualify their resistance to system voltage stress. Progress in Photovoltaics: Research and Applications 2014;22:775-783.

35. Schulze S-H, Apel A, Meitzner R, Schak M, Ehrich C, Schenider J. Influence of Polymer Properties on Potential Induced Degradation of PV-Modules. Proceedings of 28th European Photovoltaic Solar Energy Conference and Exhibition 2013:503-507. 